\title{
CSR Programs of Municipal Water Utility Companies for Wetland Communities of South Kalimantan
}

\author{
LAILA REFIANA SAID ${ }^{1}$, FIFI SWANDARI ${ }^{2}$, MELDASARI SAID ${ }^{3}$ \\ ${ }^{1}$ Faculty of Economics and Business, UNIVERSITAS LAMBUNG MANGKURAT, INDONESIA. \\ E-mail: Lrsaid@ulm.ac.id \\ ${ }^{2}$ Faculty of Economics and Business, UNIVERSITAS LAMBUNG MANGKURAT, INDONESIA. \\ E-mail: fifiswandari71@gmail.com \\ ${ }^{3}$ Sekolah Tinggi IImu Ekonomi Indonesia (STIEI) BANJARMASIN INDONESIA. E-mail: meldasaid75@gmail.com
}

\begin{abstract}
Many studies on Corporate Social Responsibility (CSR) are from private companies' perspective, analyzing social funds' effectiveness and efficiency. However, only a few studies explore CSR programs of municipal utility companies. The municipal utility company is unique because it has a captive market, and the Government regulates the company. These factors impact company's CSR strategy. The current research qualitatively analyzed the CSR of two municipal water utility companies. The Bandarmasih, located in the city of Banjarmasin, represents urban wetlands. The Intan Banjar, which service area includes Banjarbaru city and Banjar regency, represents rural wetlands. The analysis method was descriptive exploratory through observation, interviews, and focus group discussion (FGD). The results showed that the CSR programs had been sufficiently implemented but ineffective to fulfill the needs of the wetland community. The CSR programs were sporadic and did not strategically improve the companies' image. The CSR programs were not derived from the companies' vision and mission. There was no formulated social responsibility policy. This current research contributes to designing a 'signature' CSR program under its core business competencies for community welfare. This research is among the first to focus on municipal utility companies' CSR programs concerning communities in wetland areas.
\end{abstract}

Keywords: Corporate Social Responsibility; Indonesia; Municipal; Wetland

JEL Classification: H80, 13, Q56 


\section{Introduction}

Since the 1980s, companies have increasingly initiated the Corporate Social Responsibility (CSR) programs (Drumwright, 1994; Varadarajan \& Menon, 1988). More businesses believe CSR is an economic imperative in national and global markets (Sen \& Bhattacharya, 2001). The concept of CSR increasingly influences how a business runs. Some companies have rebranded their core values and incorporated the concept of CSR.

Many companies feel the need to report their various CSR activities on the company website to show that they have fulfilled their community obligations (Yongqiang, 2011). CSR aims to ensure the sustainable growth of the company. Sustainable growth is a comprehensive approach to organizations that prioritizes efforts to maximize economic, social, and environmental values. The efforts respond to fast changes in business environments faced by public and private companies (Dupire \& M'Zali, 2018).

Previous research in western countries analyzes the companies' perspectives, represented by managers' opinions about consumer reactions to corporate CSR activities rather than asking consumers directly (Maignan \& Ferrell, 2001). Several studies have developed CSR measurement models. For example, Korchagina (2012) examines CSR in Russia. However, these studies focus more on the company's point of view, analyzing its social funds' effectiveness and efficiency that potentially affect company image. A few studies are developing a model for measuring CSR programs' effectiveness, which explicitly places the community as the primary stakeholder. By placing the community as the primary stakeholder of a CSR program, it is hoped that the CSR's main goal to prosper the local community around the company will be effectively achieved.

Indonesia has a vast area of wetlands. A wetland is an area mostly inundated with water or an area with high water content. The wetland areas include swamps, mangrove forests, rivers, lakes, and various types of forests, namely flooded forest areas, peat forests, flood runoff, coastal areas, rice fields, and even coral reef environments (Faidah \& Said, 2017; Said, 2019b). Wetlands have various environmental advantages because they provide clean water, biodiversity, plant life, flood control, store groundwater reserves, and mitigate climate change.

The difference between the current and previous studies is that this study focuses on communities in wetland areas. The CSR measurement model will be aligned with the needs and characteristics of the wetlands. South Kalimantan Province is one of the important wetland areas in Indonesia. Companies should be able to implement CSR programs that satisfy the communities affected by the program. As a case example, a company carried out a cataract surgery CSR program. Everything was prepared, but it turned out that none of the people in the area had cataracts. The company did not conduct a prior survey in the areas of assistance. Even some companies do not have a clear direction for their CSR program. They wait for funding proposals from communities (Asmu'i \& Damayanti, 2015)

Previous research has attempted to measure the level of community satisfaction with the CSR program (Swandari \& Firdaus, 2013). However, a question that this paper attempts to explore is whether CSR programs developed by companies have satisfied the needs of wetland communities. This research develops a measurement model by considering the indicators of the CSR program's effectiveness to improve community welfare, thereby providing more comprehensive benefits to South Kalimantan's wetland communities. Thus, this research will complement knowledge about CSR's effectiveness from the stakeholders' perspective, especially South Kalimantan's wetland communities. Information is collected from community recipients of the company's CSR programs.

CSR has the potential to benefit a targeted population and environment while also positively impacting the organization. Ultimately, CSR programs can be effective if the program is well planned and optimized for the human and natural resources of the South Kalimantan Wetlands. 


\section{Literature Review}

\subsection{Corporate Social Responsibility (CSR)}

CSR is a mechanism for an organization to voluntarily integrate social and environmental concerns in its operation and interaction with stakeholders, which exceeds the organization's legal responsibility (Kusumadilaga, 2010). CSR is a commitment of business actors to continue to act ethically, operate legally and participate in improving the economy, the quality of life of employees and their families, and improving the community's quality of life.

The CSR program is one of the obligations that companies in Indonesia must carry out. The CSR program follows the content of Article 74 of Law No. 40 of 2007 concerning Limited Liability Companies, which discusses social and environmental responsibilities that apply to companies that manage/impact natural resources. The law requires industries or companies related to natural resource management to implement CSR programs. These industries and companies have a role in promoting healthy economic growth by considering social and environmental factors.

The Triple Bottom Line (TBL) concept describes sustainable development, which consists of financial aspects, social aspects, and environmental aspects (Elkington, 1994). The sustainability objectives are economic prosperity, environmental quality improvement, and social justice (Elkington, 1994, 1997). CSR is closely related to sustainable development. A company that intends to apply sustainable development must pay attention to the profit, the planet, and the people (the Triple P). When Triple Bottom Line and Triple P are linked, it suggests that "profit" is a form of the economic aspect, "planet" is a form of environmental aspect, and "people" is a social aspect. CSR is a strategy for companies amid an increasingly competitive business environment. CSR can provide many benefits (Susiloadi, 2008):

1. Among other factors that lead to company profitability, CSR is one factor that may promote respect for the company in the marketplace, resulting in higher sales, enhance the stock price, and be better on its financial performance.

2. CSR may reduce the risk of collisions with the surrounding community. CSR strengthens the sustainability of the company in the area by building cooperation with stakeholders.

3. CSR may improve the company's reputation, which can be seen as social marketing for the company. It is also part of corporate image building. Social marketing can provide benefits for the company's brand image.

\subsection{Corporate Social Responsibility (CSR) and Financial Performance}

The relationship between CSR and company profitability is unclear. Some argue that the implementation of CSR can increase profitability. Some are on the contrary. The implementation of CSR arguably increases profitability for several reasons.

First, CSR is about the image or reputation of the company. The correct and sustainable implementation of CSR can improve the company's image. The right image can increase profits for the company because investors believe the company can manage funds to increase profits without neglecting environmental and social aspects. Second, CSR relates to cost reduction. The costs incurred due to company environmental and social negligence cases will be minimized. Third, CSR increases productivity. Companies that care for employees (as part of the CSR program) can improve employee performance and work quality. Fourth, CSR increases the possibility of obtaining other incentives, such as tax incentives. Tax incentives can influence investors to invest, although tax incentives can positively and negatively impact an economy.

Research from Cochran \& Wood (1984) shows a positive relationship between CSR and company performance. These results are supported by Harjoto \& Jo (2011), who state that CSR affects operating performance and firm value. McWilliams \& Siegel (2000) state that the relationship between CSR and 
performance is in a neutral position. Thus, the relationship between CSR and company financial performance is still inconclusive.

\subsection{Corporate Social Responsibility (CSR) and Satisfaction Level}

Marketing management views CSR as an investment more than a cost. As an investment, the implementation of the CSR program will provide benefits for the company. The benefits obtained may create a positive image of the company from consumers' and society's perspectives. In some countries, consumers even boycott a company's products that do not carry out its social responsibility. Instead, they tend to purchase and advise others to purchase products from companies with good CSR programs.

Kotler \& Lee (2005) state that CSR can build brand positioning, boost sales, expand market share, increase employee loyalty, reduce operating costs, and increase corporate image. If CSR could provide such great benefits, the company should pay attention to CSR programs' recipients. The recipients are valuable consumers for the company. Thus, it is necessary to examine their views toward the CSR program.

\subsection{Measuring the Effectiveness of the Corporate Social Responsibility (CSR) Program}

CSR is a form of company participation in developing Indonesia. Good development should take place continuously or in sustainability. Likewise, a company's CSR program must sustain, even when the company is no longer operating. The people targeted by the program can benefit from the results and continue running the program.

According to the description above, the company's measurement of community satisfaction with the CSR program is referred to as social sustainability elements. The measure of social sustainability consists of 3 aspects: Economic, Social, and Environmental (Asy'ari, 2009). The effectiveness of CSR programs is determined by whether the predetermined goals successfully achieve or otherwise. The predetermined goals are the company's goal to carry out its CSR program with the community as the program target. The CSR predetermined goals are derived from the company's vision.

Because CSR involves various interested parties (stakeholders), the company must decide what activities are in its CSR program and how it impacts the community. The first thing that must be considered in designing a CSR program is the core competence of a business/company (Edmans, 2020). For example, when a company is involved in the beef processing business, it will be vague for the company to support a vegetarian lifestyle movement. Instead, the company's CSR program should support a movement that focuses on treating animals properly (the humane treatment of farm animals) (Edmans, 2020). Thus, it is crucial to get input from stakeholders, and from this input, an appropriate CSR program is designed.

\section{Methodology/Materials}

\subsection{Research Design}

This research is qualitative research on the CSR program of the municipal water utility companies in South Kalimantan.

\subsection{Research Subjects and Research Informants}

The research subjects were CSR programs in two municipal water utility companies of South Kalimantan, namely Bandarmasih (located in Banjarmasin City), representing urban wetlands, and Intan Banjar (located in Banjarbaru) which service area includes Banjarbaru city and Banjar regency, represents rural wetlands.

The municipal water utility companies were chosen because they partner closely with local governments in the regional development programs and are active in CSR activities. Bandarmasih is a relatively sizeable municipal water utility company located in the provincial capital, serving the most 
populous areas. Intan Banjar was chosen because it is an excellent municipal water utility company in Good Corporate Governance (GCG). Together with Badung municipal water utility company in Bali province, Intan Banjar were other Indonesian utility companies' benchmarks.

Research informants by purposive convenient sampling method were:

1. The community members who received CSR benefits.

2. The management of municipal water utility companies.

3. The employees who handle CSR programs.

The questions posed in this study:

- How was the implementation of the CSR program carried out by the municipal water utility companies?

- How was the effectiveness of the CSR program?

- What kind of CSR program fits the characteristics of the wetland community in South Kalimantan?

\subsection{Data Collection}

This study utilized primary and secondary data. Secondary data related to CSR programs were obtained from the companies, including the CSR implementation strategies. Field observations were carried out to analyze the characteristics, natural resources, and human resources of wetlands. Focus Group Discussions (FGDs) were conducted to explore the potential, interests, and expertise in the research location in the context of empowerment programs to create community welfare.

\subsection{Method of Analysis}

The analytical method used in this research was descriptive exploratory analysis. This method provides an overview of the research subjects through data or samples collected just as they are. Salient factors (Said, 2019a) were collected based on the company's data, in-depth interviews, and FGDs of urban and rural wetland communities.

Table 1 describes the categories, sub-categories, and unit analysis of research that have been determined by the researcher based on research literature. The analysis was carried out by marking the presence or absence of research parameters by giving the number ' 1 ' if there was one, otherwise giving the number ' 0 ' if there was none (Carvalho et al., 2018; Fitria \& Hartanti, 2010; Haniffa \& Cooke, 2005).

Table 1: Categories, sub-categories, and unit analysis

\begin{tabular}{|c|c|c|}
\hline Category Analysis & Sub-Category Analysis & Unit Analysis \\
\hline 1. Company Strategy & $\begin{array}{l}\text { 01. CSR program design is based on the company vision } \\
\text { 02. CSR programs are implied in the company's mission } \\
\text { 03. CSR programs are listed in the social responsibility policy company }\end{array}$ & $\begin{array}{c}\text { Concept } \\
\text { (document) }\end{array}$ \\
\hline 2. Process & $\begin{array}{l}\text { 04. Survey of the beneficiary } \\
\text { 05. Determination of CSR programs through a consensus process } \\
\text { between management and local Government based on point } 04\end{array}$ & $\begin{array}{l}\text { Concept } \\
\text { (theme) }\end{array}$ \\
\hline $\begin{array}{l}\text { 3. CSR } \\
\text { Implementation }\end{array}$ & $\begin{array}{l}\text { 06. National program implementation } \\
\text { 07. Local program implementation based on the characteristics and } \\
\text { needs of beneficiary communities } \\
\text { 08. Implementation of local programs based on community needs during } \\
\text { the Covid-19 pandemic }\end{array}$ & $\begin{array}{l}\text { Concept } \\
\text { (theme) }\end{array}$ \\
\hline 4. CSR Evaluation & $\begin{array}{l}\text { 09. Conducting community satisfaction surveys } \\
\text { 10. Conducting company image surveys } \\
\text { 11. Conducting financial performance evaluations }\end{array}$ & $\begin{array}{l}\text { Concepts } \\
\text { (themes) }\end{array}$ \\
\hline
\end{tabular}


Table 2 and Table 3 contain the semi-guided questions used in interviews and FGDs. Among others (and not limited to), the following were:

Table 2: Semi-guided interview questions

\begin{tabular}{|c|c|}
\hline No. & Questions \\
\hline 1. & Is there any vision and mission relating to the CSR program? \\
\hline 2. & What kind of CSR programs has the company implemented in the past few years? \\
\hline 3. & Are there any sustainable CSR programs? What program was found to be the most successful? Why? \\
\hline 4. & No.3, Has it continued until now? If so, why? If not, why? \\
\hline 5. & What programs do you feel are not working? Why? \\
\hline 6. & Are there any special programs during the Covid-19 pandemic? \\
\hline
\end{tabular}

Table 3: Semi-guided FGD questions

\begin{tabular}{|c|c|}
\hline No. & Questions \\
\hline 1. & Do you know about the CSR program. of ..? (based on the secondary data) \\
\hline 2. & Have you ever received the benefits of the CSR program? \\
\hline 3. & In your opinion, is the CSR program needed by the community? Why? \\
\hline 4. & What kind of CSR programs are needed for community welfare? Reason \\
\hline 5. & What programs are needed during the Covid-19 pandemic? \\
\hline
\end{tabular}

\section{Results and Findings}

\subsection{Implementation of Bandarmasih CSR Program}

The municipal water utility company's status of Bandarmasih was established in 1976 from initially owned by the Dutch Government. Bandarmasih has been the company's name to date, which services cover all Banjarmasin city. Bandarmasih's vision is 'Excellence in National Scale Water Service and Management with Global Competitiveness.' The company missions of Bandarmasih are:

1. To develop professional employees with noble character

2. To maintain the availability of sustainable water resources

3. To produce and distribute clean water consistently

4. To implement excellent service

5. To develop business diversification.

There is also a company motto expressed in the Banjar language, namely 'Banyu Kada Bewayahan.' This motto can be interpreted as 'water that never runs out.'

The research team visited the research subject in July 2020. Several FGDs and interviews were conducted. The following is a summary of the informants' responses.

\subsubsection{Is there a vision and mission in implementing CSR?}

There is no explicit vision and mission. In general, the company's CSR activities are directed by the Mayor as the owner of municipal company shares. CSR implementation is also carried out by fulfilling community requests submitted through proposals and CSR in routine activities.

\subsubsection{Explanation of the process of various CSR programs that the company has implemented in recent years:}

At the beginning of the year, many proposals were submitted to Bandarmasih, asking for funding. Proposals are collected and selected. For example, a request related to the August 17 event (the Indonesia Independence Day). The company will also synchronize CSR programs with the city 
government CSR project (Banjarmasin city government). In other words, the company's CSR activities also support government programs such as participating in cheap markets (bazaar) or donations to improve city parks. CSR activities have not been programmed and have not been continuous in fostering CSR targets. There is no vision and mission related to the company's CSR.

CSR funding comes from company profit, according to the establishment regulation, max $10 \%$. In 2019 , CSR was $5 \%$ of the profit. In 2020, $10 \%$ of the profit. The decision is based on the Mayor's Decree. During the Covid-19 pandemic, there was a $50 \%$ subsidy from the Mayor to pay the water bills for low-income communities and donate face covers to reduce their burden.

\subsubsection{Sustainable programs}

The following are considered sustainable programs: Installing ready-to-drink water in several schools, supporting GN OTA (the National Foster Parents Movement), donating through BAZNAS (National Zakat Agency), and donating mosques within the area of company water installation projects. In 2020, during the Covid-19 pandemic, various other assistance programs were temporarily postponed.

\subsubsection{The most successful programs}

The CSR programs considered the most successful are the ones that took place around the company water installation areas, the locations for the distribution of basic foodstuffs, and donations to mosques to celebrate the company anniversary or during Eid. Other successful programs include free mass circumcision of children and incentives for children of outsourcing employees.

(The critical thing to reveal is that there has never been an evaluation of these various CSR programs. So that the indicators of success cannot be clearly defined.)

\subsubsection{The critical success of the CSR program}

The continuing program is considered successful as in point $\mathrm{c}$ because the programs have been routinely implemented. The already routine programs have a low level of difficulty, especially if they are merely in the form of donation programs.

\subsubsection{Programs that did not work}

Bandarmasih carries out no CSR programs considered not successful.

\subsubsection{A particular program during the Covid-19 pandemic}

A particular program during the Covid-19 pandemic is a $50 \%$ bill reduction for Low-Income Communities.

\subsubsection{CSR information on the Bandarmasih website}

Not all of the CSR activities carried out by the company are informed on the official website.

Researchers' critical question is whether the CSR program affects company performance, such as financial performance and employee productivity.

According to Mr. Sudrajat (the research informant), the CSR program does not directly affect performance. The company never measured the impact of CSR from a financial perspective or an overall performance, however. Still, according to the informant, it will undoubtedly increase its positive image in the public view. CSR activities conducted in the community around the company will contribute to operational cost reduction if there is a conflict between the company and the community related to dangerous or disturbing activities to the surrounding community. As is well known, water utility installations' activities may have risky impacts, such as sludge disposal, noise caused by pumping machines, and generator engines. 
CSR will tie the community and the company emotionally. When the community feels close emotionally to the company, the community members will be willing to help when there is a problem. For example, they report immediately to us when there is water leakage. As a result, potential losses can be reduced.

Here, reducing the leakage rate will improve company performance. In financial terms, it will reduce the operational costs of maintenance, thus increasing company profits. In our opinion, CSR correlates to the company's profit. The increase in CSR funds' value every year indicates an increase in profit because CSR funds are calculated from company profits.

\subsection{FGD and Interviews with Bandarmasih CSR Recipients}

Meetings with CSR program recipients took place in July 2020. The participants were chairs of NGOs (Non-Governmental Organizations) and leaders of the communities. CSR beneficiaries, in this case, are referred to as the community.

In implementing the company's CSR program, the company was assisted by NGOs. The NGO recruited volunteers for CSR activities. One of the CSR programs that need volunteers was distributing free basic food packages for the needy.

For the cheap market bazaar, the bundling price of the essential food package was around IDR $50,000.00$. This package could be purchased for IDR $25,000.00$. The package usually contained: cooking oil, sugar, tea, biscuits, and syrup. According to the recipient, there were several complaints from the community regarding the bundling items and quotas. The company has determined the essential food items. The items were often not always what the buyer wanted. The items should only be sugar, cooking oil, and flour, meaning only the important ones.

The next problem was related to limited quotas. The quota policy means that not all residents could get the opportunity to buy these cheap groceries. Before the Covid-19 pandemic, cheap grocery bazaars were taken place at the company site. During the Covid-19 pandemic, cheap groceries were delivered directly to the homes of CSR program recipients.

Suggestions that can be conveyed, groceries are placed at several points. Plastic bags should be replaced with sturdy packaging because some people bring groceries back to their homes, which is quite far. The value of necessities should be increased to IDR 100,000.00. Because the quota is limited, the recipient locations should be rotated.

\subsection{Implementation of Intan Banjar CSR Program}

The next research subject was Intan Banjar. Primary data collection was carried out starting in July 2020. Intan Banjar is considering changing its status to a Limited Liability Company from its current status as a municipal company owned by the local Government of Banjarbaru city and Banjar regency. The scope of service of Intan Banjar covers Banjarbaru city and Banjar regency.

The company vision is 'To be the best among water utility companies in Indonesia.' The mission statements are:

1. To carry out the processing and distribution of clean water in a sustainable manner based on information technology.

2. To increase the competence of professional human resources and financial management transparently.

3. To carry out supervision and control to achieve efficiency and effectiveness.

The FGD and interview participants consisted of management and CSR employees. The results of the FGD are as follows.

\subsubsection{Is there a vision and mission in implementing CSR?}

There is no explicit vision and mission related to CSR. 


\subsubsection{Explanation of various CSR programs that the company has implemented in recent years:}

In general, CSR activities are carried out based on various submitted proposals. CSR funding is about $5 \%$ of the profit. The annual CSR program is stated in the Directors' Decree for the following five areas: reforestation, supporting Islamic boarding schools, free mass circumcision for children, assistance for employees' children, and funding for mosques.

\subsubsection{What kind of programs are considered sustainable?}

Reforestation, supporting Islamic boarding schools, free mass circumcision for children, assistance for employees' children, and mosques' funding.

Programs are considered sustainable because they are stated in the decree so that they are continuous programs. By stating in the decree, the programs have the power of law to support the implementation.

\subsubsection{Successful activities}

Activities considered successful are reforestation, support for Islamic boarding schools, mass circumcision, assistance for employees' children, and mosques' funding. The success indicator can be seen from the enthusiasm of the community.

\subsubsection{Continuity of activities}

These successful activities are continued because a decree supports them.

\subsubsection{Programs that did not work}

There are no CSR programs that are considered unsuccessful. All worked out.

\subsubsection{Is there a particular program during the Covid-19 pandemic?}

Special CSR activities during the Covid-19 pandemic are spraying disinfectants for houses of worship and government buildings.

\subsubsection{CSR information on the media or social media}

The distributions of free or cheap groceries are routinely published in newspapers, while those on IG (Instagram) are not updated.

\subsubsection{Does CSR influence the company's performance? (financial performance, employee}

productivity, etc.).

(Informants have difficulty linking CSR activities with productivity and company performance). It cannot measure the level of success or the relationship between CSR and performance. CSR is considered to increase achievement and increase loyalty.

\subsection{FGD and Interviews with Intan Banjar CSR Recipients}

The opinions of several group chairs of Intan Banjar CSR recipients are as follows.

We should discuss and synergize with various elements and organizations to determine and manage CSR to be more targeted and more involved in society. The CSR programs should be improved for the benefit of the people/community through a genuinely pro-community and transparency in its operations.

The CSR program will be better if it is carried out sustainably. The programs delivered, especially to the community, can have many effects on the community's welfare itself-for example, a new water installation program for low-income communities. The company must monitor the latest condition of 
customers who have received the program. With many CSR programs from the company, we expect the community to be empowered from the programs and not classified as low income.

It is hoped that the CSR programs correctly target the communities. We need community empowerment programs, such as entrepreneurship and others. Given, Intan Banjar has a good network of banks. Another example of a program is supporting Banjarbaru tourist destinations. Intan Banjar should develop potential tourist village destinations. There are still many thematic villages in Banjarbaru that can be developed through CSR programs.

Intan Banjar must be actively involved in the community and be more familiar with the community. For example, in collaboration with the neighborhood forums, Community Empowerment Institutions, Fire Brigades, and others. The open communication will make it easier for Intan Banjar to run its CSR programs so that the CSR programs provided can be right on target.

\section{Discussion}

\subsection{Analysis of CSR Programs}

The total number of research informants from the community was 15 chairmen of the CSR program beneficiary groups. Both Bandarmasih and Intan Banjar do not have companies' visions and missions related to CSR. CSR activities have not been considered a vital part of the companies' operations.

Both companies have implemented CSR programs, but the level of independence of the implementation is different. Some of the Bandarmasih CSR programs are based on the directions or adjust to the Mayor's programs, while a Directors Decree directs Intan Banjar. The CSR programs of the companies were considered successful in implementations as they become annual programs. Reports on the company's CSR program activities are usually uploaded on the company's social media. However, it is acknowledged by the management of Bandarmasih and Intan Banjar that the updating of information on CSR activities on the company's website has not been done optimally.

Another essential part is the question about the effect of CSR on performance. The two companies were neither able to explain nor measure the effect of CSR on performance. Both managements said CSR might improve its image, reduce complaints from the community affected by company operations' adverse effects, and CSR would emotionally tie the surrounding community with the company.

The difference in CSR implementation in the two companies is regarding the Non-Government Organizations (NGOs) involvement. In implementing CSR at Bandarmasih, NGOs' main task is to absorb and help handle customer complaints, while in Intan Banjar, no NGOs reported handling customer complaints. Customer complaints can be resolved quickly with the help of NGOs and volunteers. NGOs are involved because the employees of Bandarmasih are only around 400 people, while the number of customers served is around 180,000 households.

Bandarmasih CSR activities that NGOs have assisted were Go Green, which was last implemented in 2017. Also, the Bandarmasih CSR, together with its NGO partners, organized the Adiwiyata School. This activity provided outreach to school children on how to consume water wisely.

The packages of essential food for low-income people is a sustainable CSR program of Bandarmasih. Bandarmasih CSR focuses on the distribution of food necessities packages in certain selected areas. The program has been regularly carried out for years. Bandarmasih CSR program recently has focused heavily on providing basic foodstuffs. The basic foodstuffs cost IDR 100,000.00, which can be redeemed at a lower price. The items such as sugar, cooking oil, syrup, tea, and biscuits. Based on the opinion of the informant, the items are not all that the community needs.

From the companies' FGDs, all CSR activities were deemed to be going well. The indicator of good or bad is not known with certainty. This unknown is due to the absence of a definite benchmark/measure of CSR activity's success. Unavailable measurement made it challenging to evaluate activities. Activities will be the same from time to time. On the other hand, community demands are getting higher from time to time. 
Table 4 shows the coding results for Bandarmasih. CSR program design has not become part of the company's strategy. The CSR programs have not been determined through a consensus process between management and local Government based on a beneficiary survey. The CSR program's implementation is categorized quite well because it includes national programs, namely GN-OTA and Baznas. Also, the community's perceptions of who are beneficiaries of the CSR program are quite positive so that they are considered to have fulfilled activities following community needs. Bandarmasih is also quite responsive to disaster situations, in this case, the Covid-19 pandemic. Bandarmasih carries out activities aimed at reducing the community's burden due to the pandemic so that the company is considered sufficiently concerned about the needs of the community in times of emergency.

Table 4: The coding results of CSR Bandarmasih

\begin{tabular}{|c|c|c|}
\hline Category Analysis & Sub-category analysis & Coding \\
\hline 1. Company Strategy & $\begin{array}{l}\text { 01. CSR program design is based on the company vision } \\
\text { 02. CSR programs are implied in the company's mission } \\
\text { 03. CSR programs are listed in the social responsibility policy company }\end{array}$ & $\begin{array}{l}0 \\
0 \\
0\end{array}$ \\
\hline 2. Process & $\begin{array}{l}\text { 04. Survey of the beneficiary } \\
\text { 05. Determination of CSR programs through a consensus process between } \\
\text { management and local Government based on point } 04\end{array}$ & $\begin{array}{l}0 \\
0\end{array}$ \\
\hline $\begin{array}{c}\text { 3. CSR } \\
\text { Implementation }\end{array}$ & $\begin{array}{l}\text { 06. National program implementation } \\
\text { 07. Local program implementation based on the characteristics and needs of } \\
\text { beneficiary communities } \\
\begin{array}{c}\text { 08. Implementation of local programs based on community needs during the } \\
\text { Covid-19 pandemic }\end{array}\end{array}$ & 1 \\
\hline 4. CSR Evaluation & $\begin{array}{l}\text { 09. Conducting community satisfaction surveys } \\
\text { 10. Conducting company image surveys } \\
\text { 11. Conducting financial performance evaluations }\end{array}$ & $\begin{array}{l}0 \\
0 \\
0\end{array}$ \\
\hline
\end{tabular}

Table 5: The coding results of Intan Banjar

\begin{tabular}{|c|c|c|}
\hline Category Analysis & Sub-category analysis & Coding \\
\hline 1. Company Strategy & $\begin{array}{l}\text { 01. CSR program design is based on the company vision } \\
\text { 02. CSR programs are implied in the company's mission } \\
\text { 03. CSR programs are listed in the social responsibility policy company }\end{array}$ & $\begin{array}{l}0 \\
0 \\
0\end{array}$ \\
\hline 2. Process & $\begin{array}{l}\text { 04. Survey of the beneficiary } \\
\text { 05. Determination of CSR programs through a consensus process between } \\
\text { management and local Government based on point } 04\end{array}$ & $\begin{array}{l}0 \\
0\end{array}$ \\
\hline $\begin{array}{c}\text { 3. CSR } \\
\text { Implementation }\end{array}$ & $\begin{array}{l}\text { 06. National program implementation } \\
\begin{array}{l}\text { 07. Local program implementation based on the characteristics and needs of } \\
\text { beneficiary communities }\end{array} \\
\begin{array}{c}\text { 08. Implementation of local programs based on community needs during the } \\
\text { Covid-19 pandemic }\end{array}\end{array}$ & $\begin{array}{l}0 \\
1\end{array}$ \\
\hline 4. CSR Evaluation & $\begin{array}{l}\text { 09. Conducting community satisfaction surveys } \\
\text { 10. Conducting company image surveys } \\
\text { 11. Conducting financial performance evaluations }\end{array}$ & $\begin{array}{l}0 \\
0 \\
0\end{array}$ \\
\hline
\end{tabular}

Table 5 shows the coding results for Intan Banjar. Like Bandarmasih, the CSR program's design for Intan Banjar has not become part of its strategy. The CSR programs have not been determined through a consensus process between management and local Government based on a beneficiary survey. Intan Banjar's CSR program does not yet reflect support for the national program. On the other hand, the community's perceptions of the CSR program's beneficiaries are positive enough that they are considered to have fulfilled activities following community needs. Intan Banjar is also quite responsive to the Covid-19 pandemic situation. Intan Banjar is also carrying out activities aimed at reducing the 
community's burden due to the pandemic so that the company is deemed sufficiently concerned about the community's needs in times of emergency.

\subsection{The Effectiveness of the CSR Program for the Wetland Communities of South Kalimantan}

Effectiveness can be defined in terms of whether the CSR goals have been achieved or otherwise. Companies that look for an effective CSR program must start by setting their objectives of the program. The objectives should be stated in its strategic plan based on its vision and mission. The CSR objectives will be compared to the achievement of the programs or activities implemented. Companies that carry out CSR ideally make CSR programs/activities that follow the community's wishes and expectations.

It is essential to understand the characteristics of the municipal utility company. The municipal utility company's characteristics are unique in that they are regulated by the Regional Government and may impact the measurement methodology in terms of CSR strategies (Cunningham, 2014). The Regional Government's expectations are one factor that influences municipal utility companies in carrying out CSR programs. Therefore, the CSR program becomes the concern and interest of the Regional Government.

The water utility company is a regional government-owned enterprise. The company functions as a tool for the Regional Government to serve the public within its administrative area. In the regional economic system, the municipal water utility company is expected to balance market forces and increase regional income through dividend payment to the Regional Government.

The Republic of Indonesia's first law regulating utility companies as a regionally owned company was Law No. 5 of 1962 concerning Regional Companies (Law 5/1962) (Muslikah, 2015; UU No. 5 Tahun 1962 Tentang Perusahaan Daerah, 1962). Article 2 of Law 5/1962 states, 'Regional Companies are all companies established under this law whose capital is wholly or partly separated regional assets unless otherwise stipulated by or based on Law (UU No. 5 Tahun 1962 Tentang Perusahaan Daerah, 1962).

Law 23/2014 on Regional Government changed the name 'Regional Company' to Regional Government-Owned Enterprise because Article 1, number 40 of Law 23/2014 defines Regional Government-Owned Enterprise as a business entity that is wholly or most of its capital owned by the Region (UU Nomor 23 Tahun 2014 Tentang Pemerintahan Daerah, 2014). Regulations directly related to Regional Government-Owned Enterprise are Law 23/2014 and Government Regulation No. 54 of 2017 concerning Regional Owned Enterprises (Peraturan Pemerintah No. 54 Tahun 2017 Tentang Badan Usaha Milik Daerah, n.d.).

The relationship between municipal utility companies and their consumers also has unique characteristics. Consumers can not choose a water service provider because the municipal water utility company is a single water provider in each region. In this case, a municipal water utility company's customers are categorized as a 'captive audience' (Cunningham, 2014).

CSR studies in western countries show that customers at public service companies appreciate a bill reduction program that directly benefits them than other CSR activities (Cunningham, 2014). Bandarmasih and Intan Banjar have implemented a water bill reduction program projected for lowincome communities, especially during the Covid-19 pandemic.

Like public service companies in western countries, the municipal water utility companies tend to direct their social funding towards local organizations and local programs rather than supporting national programs. However, Bandarmasih has CSR activities related to the GN-OTA and Baznas national programs of Indonesia, while Intan Banjar chooses not to participate in the available national programs.

Studies show that many companies do not survey areas where assistance is needed. Some companies do not even have a clear direction for their CSR programs. They wait for donation request proposals from the community (Asmu'i \& Damayanti, 2015). For the case of Bandarmasih, its CSR program has been directed by the Mayor for years. Intan Banjar is somewhat different. Intan Banjar's CSR program is based on a board of directors' decree. Nevertheless, both are not based on a survey of the needs of CSR recipients. 
The current study proposes that measuring the CSR program's effectiveness must include indicators related to stakeholders' involvement. These indicators include community feedbacks and Government approval. For example, as suggested by one of the research informants, the company should cooperate and communicate with the neighborhood forums, Community Empowerment Institutions, and the Fire Departments.

Good communication will open new ideas in the CSR program implementation. Various potential resources in both the Bandarmasih and Intan Banjar regional areas could be better explored. For example, intensive communication between the company and the community around the floating market can generate new ideas to develop the tourism area further. The Bandarmasih motto of 'Banyu Kada Bewayahan,' which means water that never runs out (abundance), can be directed to support the river conservation program. The socialization program of the river cleanliness to the community needs to be done because many residents throw garbage into the river (Putra et al., 2017; Qureshi, Muhammad Imran, et al. 2020). The CSR program can also collaborate with neighborhood forums for household waste management concerning non-organic waste to the river. Optimization of floating market tourism and other related water business as the core business competence is the company's potential CSR program in South Kalimantan's wetlands.

Intan Banjar's mission implicitly states the importance of information technology. Intan Banjar's signature CSR program can be related to the 'Movement Towards 100 Smart Cities'. This movement is a national program initiated by the Ministry of Communication and Information Technology, the Ministry of Home Affairs, the Ministry of Public Works and Public Housing, the Ministry of National Development Planning, and the presidential staff office with the aim of the Regional Government being able to maximize the use of technology in improving services to the community. Through a national selection process, 50 districts/cities were selected, including the city of Banjarbaru, in planning the technology-based smart city.

Cultural and religious tourism is a potential for Banjar regency, which is characterized by strong Islamic culture. The city of Martapura is the capital of Banjar Regency, called Serambi Mekkah, because the Islamic atmosphere is strongly felt in Banjar Regency, especially in Martapura. The city of Martapura is also famous for diamond minings. Intan Banjar CSR programs can support public facilities, traditional markets, gemstone markets, and protection of historic buildings (heritage buildings) as national and international tourist destinations.

South Kalimantan's wetlands' natural resources need attention and can become the companies' signature CSR program. Local vegetables need to be promoted, and local wisdom needs to be socialized. Some examples of typical wetland vegetables that are being forgotten by modern society are the genjer, kangkung air, keladi, sulur keladi, and supan-supan (Susanti, 2015). The CSR program can support research on foodstuffs' processing of local vegetables. Programs may include coaching and training the Micro, Small, and Medium Enterprises (MSMEs) for marketing local foods.

An effective CSR program should consider these factors:

- Knowledge of the characteristics of the form of business/organization and core competencies of the business

- Knowledge of the characteristics of the community in which the company operates

- CSR programs' design is based on the relationship between its vision and mission and the local community's needs based on a preliminary survey.

- A consensus process between management and the Government as the shareholder to implement a CSR program based on the beneficiary community's characteristics and needs.

- Evaluation of CSR programs, among others, through community satisfaction surveys, perceptions of corporate image, and financial performance.

Table 6 and Table 7 contain examples of the formulation of each company's potential signature CSR programs by considering the factors mentioned above. The effectiveness of the signature CSR program 
is then measured through a survey of community satisfaction (short-term), perceived corporate image (medium-term), and financial performance (long-term).

Table 6: Formulation of the signature CSR program of Bandarmasih.

\begin{tabular}{|c|c|c|c|}
\hline Vision-Mission-Motto & CSR Implementation & $\begin{array}{l}\text { Community } \\
\text { Feedback }\end{array}$ & $\begin{array}{l}\text { Potential Signature } \\
\text { CSR Programs }\end{array}$ \\
\hline $\begin{array}{c}\text { Vision: Excellence in } \\
\text { National Scale Water } \\
\text { Service and } \\
\text { Management with } \\
\text { Global } \\
\text { Competitiveness. } \\
\text { Mission: } \\
\text { To develop } \\
\text { professional } \\
\text { employees with noble } \\
\text { character. } \\
\text { To maintain the } \\
\text { availability of } \\
\text { sustainable water } \\
\text { resources } \\
\text { To produce and } \\
\text { distribute clean water } \\
\text { consistently } \\
\text { To implement } \\
\text { excellent service } \\
\text { To develop business } \\
\text { diversification. } \\
\text { Moto: Banyu Kada } \\
\text { Bewayahan }\end{array}$ & 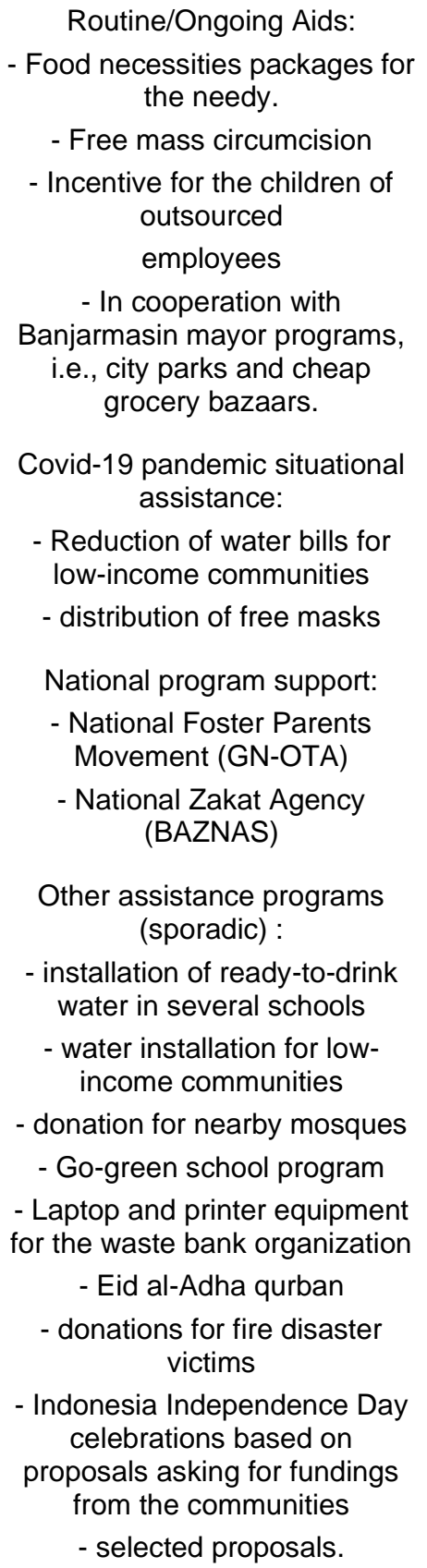 & $\begin{array}{l}\text { - More focus on } \\
\text { environmental care } \\
\text { programs } \\
\text { - Training and } \\
\text { assisting MSMEs }\end{array}$ & $\begin{array}{l}\text { Following the uniqueness } \\
\text { of Banjarmasin city as } \\
\text { called 'the city of a } \\
\text { thousand rivers,' CSR } \\
\text { programs proposed: } \\
\text { - Supporting river } \\
\text { conservation, socializing } \\
\text { the importance of clean } \\
\text { rivers to the community, } \\
\text { optimizing floating market } \\
\text { tourism and other water- } \\
\text { related business (based } \\
\text { on the core business } \\
\text { competence of } \\
\text { Bandarmasih). } \\
\text { - Supporting other } \\
\text { wetlands environmental } \\
\text { awareness programs. } \\
\\
\text { - MSMEs training and } \\
\text { assistance programs, } \\
\text { especially those that } \\
\text { support the potential for } \\
\text { the empowerment of } \\
\text { natural resources and } \\
\text { expertise in wetland } \\
\text { communities, such as } \\
\text { supporting woven } \\
\text { handicrafts, local foods, } \\
\text { etc., to promote } \\
\text { Banjarmasin city tourism. }\end{array}$ \\
\hline
\end{tabular}


Table 7: Formulation of the signature CSR program of Intan Banjar

\begin{tabular}{|c|c|c|c|}
\hline Vision Mission & CSR Implementation & Community Feedback & $\begin{array}{c}\text { Potential Signature CSR } \\
\text { Programs }\end{array}$ \\
\hline $\begin{array}{l}\text { Mission: } \\
\text { 1.To carry out the } \\
\text { processing and } \\
\text { distribution of clean } \\
\text { water in a } \\
\text { sustainable manner } \\
\text { based on } \\
\text { information } \\
\text { technology. } \\
\text { 2.To increase the } \\
\text { competence of } \\
\text { professional human } \\
\text { resources and } \\
\text { financial } \\
\text { management } \\
\text { transparently. } \\
\text { 3.To carry out } \\
\text { supervision and } \\
\text { control to achieve } \\
\text { efficiency and } \\
\text { effectiveness. }\end{array}$ & $\begin{array}{l}\text { Routine/Ongoing Aids: } \\
\text { Five areas as follows: } \\
\text { - reforestation } \\
\text { - supporting Islamic } \\
\text { boarding schools } \\
\text { - free mass } \\
\text { circumcision } \\
\text { - aid to children of } \\
\text { employees } \\
\text { - supporting mosques. } \\
\text { Covid-19 pandemic } \\
\text { situational assistance: } \\
\text { - spraying disinfectant } \\
\text { for houses of worship } \\
\text { and government } \\
\text { agency buildings. } \\
\\
\text { Other assistance } \\
\text { programs (sporadic): } \\
\text { - distribution of basic } \\
\text { foodstuffs } \\
\text { - selective programs } \\
\text { based on funding } \\
\text { proposals from } \\
\text { communities. }\end{array}$ & $\begin{array}{l}\text { - Discuss and synergize } \\
\text { with communities and } \\
\text { organizations to determine } \\
\text { and manage CSR to be } \\
\text { more targeted and more } \\
\text { involved in society. } \\
\text { - Transparency in CSR } \\
\text { funding. } \\
\text { - Supporting community } \\
\text { empowerment programs, } \\
\text { entrepreneurship. } \\
\text { - Fostering tourism villages } \\
\text { - Having collaborations } \\
\text { with the neighborhood } \\
\text { Forums, community } \\
\text { empowerment } \\
\text { organizations, Fire } \\
\text { Brigades, and others. }\end{array}$ & $\begin{array}{l}\text { Based on the interest reflected } \\
\text { in Intan Banjar's mission in } \\
\text { information technology } \\
\text { applications, the potential } \\
\text { signature program might be } \\
\text { supporting Banjarbaru as a } \\
\text { Smart city (part of the national } \\
\text { program). } \\
\text { - Supporting the river } \\
\text { conservation program, } \\
\text { socialization of the importance } \\
\text { of river's cleanliness to the } \\
\text { community, optimization of } \\
\text { floating market tourism, and } \\
\text { other water-related business } \\
\text { (based on the core business } \\
\text { competence of Intan Banjar. } \\
\text { - MSMEs training and } \\
\text { assistance programs, } \\
\text { especially those that support } \\
\text { the potential for empowerment } \\
\text { of natural resources and } \\
\text { expertise in wetland human } \\
\text { resources. Example; } \\
\text { supporting handicrafts } \\
\text { wovens, food, tours, and other } \\
\text { activities relating to tourist } \\
\text { visits. } \\
\text { - Supporting the development } \\
\text { of public facilities for cultural } \\
\text { and religious tourism. }\end{array}$ \\
\hline
\end{tabular}

\section{Conclusion}

The Bandarmasih CSR program's implementation is based on the Mayor's direction as the company's shareholder. Meanwhile, Intan Banjar CSR implementation is based on the company Director's Decree, a product of the board of directors meeting.

The CSR programs of the two companies have been implemented quite well but are categorized as ineffective based on the failure to fulfill the following indicators of the CSR effectiveness measurement model:

- The CSR program designs have not been based on the company's vision and mission.

- The CSR program designs have not been based on the characteristics of the community in which the company operates

- The CSR program's designs have not been based on the relationship between its vision and mission and the national program according to the local community's needs based on a preliminary survey.

- The choice of CSR programs has not gone through an evaluation process between management and the local Government as its shareholder, based on the beneficiary community's characteristics and needs.

- Evaluation of CSR programs through community satisfaction surveys, perceived corporate image, and financial performance has not been implemented. 
In general, the CSR programs being studied are sporadic, not strategic to improve the company's image; there is no clear vision and mission, and no social responsibility policy found in both companies. It is suggested that the company should set CSR programs and objectives based on its vision and mission. These objectives will then be used as a measure of the successful implementation of the CSR program. Therefore, the management should determine CSR programs systematically, on target, and measurably according to community needs and society's welfare. By following those steps, it can be expected that Bandarmasih and Intan Banjar's corporate images will be better and more successful.

It is quite challenging for municipal water utility companies to focus their programs on critical social issues through specific or unique CSR programs from a strategic perspective. This challenge situation is because the customers are broadly varied. Therefore, to meet many people's expectations, it is not surprising that municipal water utility companies tend to carry out sporadic activities by simply fulfilling proposals for funding requests from the community.

Even so, the companies should continue to improve themselves to develop a better corporate image. Companies can cooperate with the organization, nationally and internationally, which is related to its core business competence so that the activities carried out are more focused and sustainable. Each company can have a signature CSR program considering its vision and mission, core business competence, and South Kalimantan's wetland communities' needs.

This study has several limitations. First, field observation data could not be maximally conducted due to the Covid-19 pandemic, which did not allow researchers to inspect the CSR program's location beneficiary areas. Second, a content analysis of the company website has not been carried out. Secondary data only came from company documents. Future research should complement data collection by conducting a content analysis of corporate communication media. Third, this study has not examined the evaluation of CSR programs. Future research should be able to include the analysis of community satisfaction surveys (short-term), perceptions of corporate image (medium-term), and financial performance (long-term).

\section{Acknowledgment:}

This research was supported by Universitas Lambung Mangkurat. We thank our colleagues from Bandarmasih and Intan Banjar, who provided insight and expertise that greatly assisted the research.

\section{References}

1. Asmu'i, H., \& Damayanti, V. P. (2015). Kemiskinan Masyarakat Petani di Kecamatan Gambut dan Corporate Social Responsibility dalam Implementasinya. Potensi, Peluang, Dan Tantangan Pengelolaan Lingkungan Lahan Basah Secara Berkelanjutan.

2. Asy'ari, H. (2009). Implementasi Corporate Social Responsibility (CSR) sebagai Modal Social pada PT Newmont. Universitas Diponegoro.

3. Carvalho, F., Santos, G., \& Gonçalves, J. (2018). The Disclosure of Information on Sustainable Development on the Corporate Website of the Certified Portuguese Organizations. International Journal for Quality Research, 12(1), 253-276.

4. Cochran, P., \& Wood, R. A. (1984). Corporate Social Responsibility and Performance. The Academy of Management Journal, 27(1), 42-56.

5. Cunningham, C. (2014). Measuring The Impact of Corporate Social Investments. www.conferenceboard.org

6. Drumwright, M. E. (1994). Socially Responsible Organizational Buying: Environmental Concern as a Noneconomic Buying Criterion. Journal of Marketing, 58(3), 1-19. https://doi.org/10.2307/1252307

7. Dupire, M., \& M'Zali, B. (2018). CSR strategies in response to competitive pressures. Journal of Business Ethics, 148(3), 603-623. 
8. Edmans, A. (2020). Grow the Pie: How Great Companies Deliver Both Purpose and Profit. Cambridge University Press.

9. Faidah, A. N., \& Said, L. R. (2017). Pemanfaatan Kekayaan Alam Lahan Basah Untuk Peningkatan Pendapatan Keluarga (Studi Pada Masyarakat Tepian Sungai Alalak Kalimantan Selatan). September.

10.Fitria, S., \& Hartanti, D. (2010). Islam dan tanggung Jawab Sosial: Studi Perbandingan Pengungkapan Berdasarkan Global Reporting Initiative Indeks dan Islamic Sosial Reporting Indeks: Studi Empiris pada Perusahaan Perbankan. Purwokerto. Simposium Nasional Akuntansi XIII, 1-46.

11.Haniffa, R. M., \& Cooke, T. E. (2005). The Impact of Culture and Governance on Corporate Social Reporting. Journal of Accounting and Public Policy, 24(5), 391-430. https://doi.org/10.1016/j.jaccpubpol.2005.06.001

12. Harjoto, M. A., \& Jo, H. (2011). Corporate Governance and CSR Nexus. Journal of Business Ethics, $100(1), 45-67$.

13.Korchagina, E. (2012). The Assessment Of Corporate Social Performance Effectiveness : Russian Case.

14.Kotler, P., \& Lee, N. (2005). Corporate Social Responsibility: Doing the Most Good for Your Company and Your Cause. Wiley. https://books.google.co.id/books?id=2DgIQE0s95EC

15. Kusumadilaga, R. (2010). Pengaruh Corporate Social Responsibility Terhadap Nilai Perusahaan Dengan Profitabilitas Sebagai Variabel Moderating (Studi Empiris pada Perusahaan Manufaktur yang terdaftar di Bursa Efek Indonesia) [Universitas Diponegoro]. http://eprints.undip.ac.id/22572/

16.Maignan, I., \& Ferrell, O. . (2001). Antecedents and Benefits of Corporate Citizenship: An Investigation of French Businesses. Journal of Business Research, 51(1), 37-51. https://doi.org/10.1016/S0148-2963(99)00042-9

17.McWilliams, A., \& Siegel, D. (2000). Corporate social responsibility and financial performance: correlation or misspecification? Strategic Management Journal, 21(5), 603-609. https://doi.org/10.1002/(SICI)1097-0266(200005)21:5<603::AID-SMJ101>3.0.CO;2-3

18. Muslikah, F. E. (2015). Penyertaan Modal Pemerintah Daerah Kota Depok Pada Perusahaan Daerah Air Minum (PDAM) Kota Depok. Universitas Indonesia.

19.Peraturan Pemerintah No. 54 Tahun 2017 tentang Badan Usaha Milik Daerah.

20.Qureshi, Muhammad Imran, et al. "Classifications of sustainable manufacturing practices in ASEAN region: A systematic review and bibliometric analysis of the past decade of research." Sustainability 12.21 (2020): 8950.

21.Said, L. R. (2019a). Eliciting Salient Factors in Online Shopping Behavior Research. 3(2), 8-13.

22.Said, L. R. (2019b). Woman entrepreneurs in rural wetlands: Overcoming resistance to change. Restaurant Business, 118(11), 506-517.

23.Sen, S., \& Bhattacharya, C. B. (2001). Does Doing Good Always Lead to Doing Better? Consumer Reactions to Corporate Social Responsibility. Journal of Marketing Research, 38(2), 225-243. http://www.jstor.org/stable/1558626

24.Susanti, H. (2015). Studi Etnobotani Sayuran Lokal Khas Rawa di Pasar Martapura Kalimantan Selatan. Ziraa'ah Majalah Ilmiah Pertanian, 40(2), 140-144.

25.Susiloadi, P. (2008). Implementasi Corporate Social Responsibility untuk Mendukung Pembangunan Berkelanjutan. Universitas Sebelas Maret.

26.Swandari, F., \& Firdaus, M. R. (2013). Penggunaan Explanatory Factor Analysis Untuk Mengukur Kepuasan Masyarakat Terkait Penerapan Program CSR. Universitas Gadjah Mada Doctoral Colloquium.

27.UU No. 5 Tahun 1962 tentang Perusahaan Daerah, (1962).

28.UU Nomor 23 Tahun 2014 tentang Pemerintahan Daerah, (2014).

29.Varadarajan, P. R., \& Menon, A. (1988). Cause-Related Marketing: A Coalignment of Marketing Strategy and Corporate Philanthropy. Journal of Marketing, 52(3), 58-74. https://doi.org/10.2307/1251450 
30.Yongqiang, G. (2011). CSR in an emerging country: a content analysis of CSR reports of listed companies. Baltic Journal of Management, 6(2), 263-291. https://doi.org/10.1108/17465261111131848 